\title{
Under recognition of late onset ornithine transcarbamylase deficiency
}

\author{
R E H Schultz, M K Salo
}

\begin{abstract}
Late onset ornithine transcarbamylase deficiency (McKusick 311250) is reported in four Finnish patients, two boys and two heterozygous girls. The subtle onset and course of ornithine transcarbamylase deficiency emphasises the need for plasma ammonia and amino acid measurements in clinical situations suggesting a disorder of this nature.
\end{abstract}

(Arch Dis Child 2000;82:390-391)

Keywords: urea cycle defect; ornithine transcarbamylase deficiency; late onset disease; under recognition; genetics

Deficiency of the mitochondrial matrix enzyme transcarbamylase leads to the most common defect of the urea cycle resulting in a serious impairment of ammonia metabolism. The defect is inherited as an X linked trait. If untreated, symptoms include impairment of consciousness, vomiting, convulsion, coma, and death. In the past 15 years there have been numerous case reports of homozygous men with a fatal late onset course of the disease. ${ }^{12}$ Despite the growing number of cases the disorder is still under recognised, especially in boys.

Pediatrics, University

Hospital Tampere, PO

Box 2000, 33521

Tampere, Finland

R E H Schultz

M K Salo

Correspondence to:

Dr Schultz

email: 1lrusc@uta.fi

Accepted 1 February 2000 to a paediatric surgical ward. Because of bouts of aggression and odd behaviour, encephalitis was suspected and the patient transferred to a paediatric intensive care unit. There his condition varied between weariness and almost normal. On day 9 he became unconscious, vomited, and was incontinent of faeces. His pupils became enlarged and non-responsive to light. Laboratory studies revealed hyperammonaemia, increased glutamine $(1387 \mu \mathrm{mol} / \mathrm{l})$, decreased citrulline $(3 \mu \mathrm{mol} / \mathrm{l})$, and increased urinary orotate $(365.8 \mu \mathrm{mol} / \mathrm{mmol}$ creatinine $)$. Despite emergency treatment he died on day 14 from massive cerebral oedema.

Symptoms in patient 2 appeared concomitantly with the birth of her sister and were misinterpreted as signs of jealousy. On laboratory examination the first urinary orotate was in the normal range and carbamoyl phosphate synthetase deficiency was suggested. A second analysis revealed high concentrations of orotate (1304 $\mu \mathrm{mol} / \mathrm{mmol}$ creatinine).

Patient 3 was referred to hospital because the examiner could not obtain visual contact with the patient and a metabolic disorder was suspected. Her mother has recently given birth to another boy (patient 5) who is carrying the same mutation as patient 3 and was immediately started on a low protein diet, oral arginine, citrulline, and phenylbutyrate.

Patient 4 was formerly well but his parents revealed a long standing aversion to a diet rich in protein, and symptoms which had been interpreted as defiance. The child was admitted to a paediatric emergency room where a metabolic disorder was suspected, leading to measurements of plasma ammonia and amino acids.

Table 1 Patient details

\begin{tabular}{|c|c|c|c|c|c|}
\hline & Age at onset & Initial symptoms & Initial investigations & DNA analysis & Outcome \\
\hline $\begin{array}{r}\text { Patient } 1 \\
\text { (male) }\end{array}$ & 5 years & $\begin{array}{l}\text { Running into a wall, nausea, } \\
\text { vomiting }\end{array}$ & $\begin{array}{l}\text { EEG with slow delta waves, CCT } \\
\text { normal, Total blood count and C } \\
\text { reactive protein normal, ALT slightly } \\
\text { elevated, } \mathrm{NH}_{4}^{+} \text {initially not taken, later } \\
\text { clearly elevated }(400-906 \mu \mathrm{mol} / \mathrm{l})\end{array}$ & $\begin{array}{l}\mathrm{G}>\mathrm{A} \text { exchange of the first base of } \\
\text { codon } 208 \text { changing alanine to } \\
\text { threonine. Typical for late onset } \\
\text { disease in } \text { males }^{3}\end{array}$ & Died on day 14 \\
\hline $\begin{array}{l}\text { Patient } 2 \\
\quad(\text { female })\end{array}$ & $31 / 2$ years & $\begin{array}{l}\text { Attacks of absence, } \\
\text { increasing signs of } \\
\text { aggression, confusion, } \\
\text { sleeplessness, atetotic } \\
\text { movements of upper limbs }\end{array}$ & $\begin{array}{l}\text { EEG with signs of general disturbance on } \\
\text { both hemispheres, slight } \\
\text { hyperammonaemia }(123 \mu \mathrm{mol} / \mathrm{l}) \text {, ALT } \\
\text { elevated }(299 \mathrm{U} / 1) \text {, citrulline decreased } \\
(13 \mu \mathrm{mol} / 1) \text {, first urinary orotate was } \\
\text { normal }\end{array}$ & $\begin{array}{l}\text { Heterozygosity for an } \mathrm{A}>\mathrm{G} \text { mutation } \\
\text { in codon } 80 \text { changing lysine into } \\
\text { glutamic acid; not formerly } \\
\text { described }\end{array}$ & $\begin{array}{l}\text { Alive, development } \\
\text { almost normal, } \\
\text { disease under } \\
\text { control }\end{array}$ \\
\hline $\begin{array}{r}\text { Patient } 3 \\
\text { (male) }\end{array}$ & 1 year 3 months & $\begin{array}{l}\text { Increasing weariness, } \\
\text { crying, restlessness, } \\
\text { vomiting }\end{array}$ & $\begin{array}{l}\text { CCT normal, ALT elevated }(102 \mathrm{U} / 1) \\
\mathrm{NH}_{4}^{+} \text {, fluctuating }(67-218-146 \mu \mathrm{mol} / 1) \\
\text { citrulline decreased }(<10 \mu \mathrm{mol} / \mathrm{l}) \\
\text { urinary orotate elevated }(220 \\
\mu \mathrm{mol} / \mathrm{mmol} \text { creatinine })\end{array}$ & $\begin{array}{l}\text { Abnormal migration pattern at exon } \\
8 \text { with a deletion of a GAG triplet } \\
\text { corresponding to codon } 272 \text { or } \\
273 \text { causing deletion of one } \\
\text { adjacent glutamic acid residue. } \\
\text { Formerly described for late } \text { onset }^{5}\end{array}$ & $\begin{array}{l}\text { Alive, development } \\
\text { almost normal, } \\
\text { disease under } \\
\text { control }\end{array}$ \\
\hline $\begin{array}{l}\text { Patient } 4 \\
\quad(\text { female })\end{array}$ & 4 years 8 months & $\begin{array}{l}\text { Outbursts of rage and fury, } \\
\text { clumsy walk, slurred } \\
\text { speech, emotional lability }\end{array}$ & $\begin{array}{l}\text { ALT elevated }(64-119 \mathrm{U} / 1), \mathrm{NH}_{4}^{+} \\
\text {fluctuating }(143-201-124 \mu \mathrm{mol} / \mathrm{l}) \text {, low } \\
\text { citrulline }(13 \mu \mathrm{mol} / \mathrm{l}), \text { urinary orotate } \\
\text { elevated }(95 \mu \mathrm{mol} / \mathrm{mmol} \text { creatinine })\end{array}$ & $\begin{array}{l}\text { Abnormal migration pattern in exon } \\
3 \text { with a CGA (Arg) to CAA (Gln) } \\
\text { mutation of codon } 92 . \text { One of the } \\
\text { first mutations described }\end{array}$ & $\begin{array}{l}\text { Alive, development } \\
\text { normal, disease } \\
\text { under control }\end{array}$ \\
\hline [Patient 5] & $\begin{array}{l}\text { The pa } \\
\text { mutatic }\end{array}$ & \multicolumn{4}{|c|}{$\begin{array}{l}\text { The patient is a brother of patient } 3 \text { and was therefore neonatally screened for ornithine transcarbamylase deficiency and revealed the same } \\
\text { mutation as his brother (see patient } 3 \text { ). He was initially treated and yet had no episodes of hyperammonaemia. His development is normal }\end{array}$} \\
\hline
\end{tabular}




\section{Discussion}

In all four patients onset of symptoms occurred after one month of age which is in concert with the definition of late onset disease. All had an initially slightly high alanine aminotransferase (ALT, see table 1). One patient died and this may have been preventable if a metabolic disorder had been suspected. DNA analysis revealed a mutation which seems to be very typical for late onset disease with a lethal outcome. ${ }^{3}$ Patients 2 and 4 were both heterozygous girls with milder symptoms, interpreted by their parents as jealousy or defiance. Patient 3 benefited from two facts which may have saved his life. Firstly he presented with symptoms at a relatively young age, which motivated his general practitioner to refer him to hospital care. Secondly he was admitted to a hospital located in an area with a relatively high incidence of metabolic disorders, which resulted in the immediate suspicion of a metabolic disease; plasma ammonia and amino acids were measured.

Recent research on the biochemical and molecular picture of ornithine transcarbamylase deficiency revealed a wide spectrum of genetic defects which results in different phenotypes. ${ }^{16}$ Oppliger Leibundgut et $a l^{6}$ have shown that there may be poor correlation between residual enzyme activity in vitro and the clinical course of the disorder, which makes ornithine transcarbamylase deficiency unpredictable. Additionally, investigation of a large number of patients by Tuchman et $a l^{1}$ has shown that of all reported mutations which resulted in a late onset course, $50 \%$ occurred in boys. This matches with late onset cases in Finland diagnosed during the last 10 years, of which seven of the 14 new cases were men; the oldest one was diagnosed at the age of 18 years. The aim of our report is to remind clinicians that late onset ornithine transcarbamylase deficiency occurs at almost any age, half are boys, and unexplained symptoms such as rage, fury, confusion, or simply acting in an odd way should provoke paediatricians to measure plasma ammonia, amino acids, and transaminases.

This work was supported by a grant from the Research Fund of the University Hospital of Tampere.

1 Tuchman M, Morizono H, Rajagopal BS, Plante RJ, Allewell NM. The biochemical and molecular spectrum of Allewell NM. The biochemical and molecular spectrum of ornithine transcarbamylase
1998;21(suppl 1):40-58.

2 Finkelstein JE, Hauser ER, Leonard CO, Brusilow SW. Late-onset ornithine transcarbamylase deficiency in male patients. F Pediatr 1990;17:897-902

3 Van Diggelen OP, Zaremba WH, Keulemans JLM, et al. Asymptomatic and late-onset ornithine transcarbamylase (OTC) deficiency in males of a five-generation family, caused by an A208T mutation. Clin Genet 1996;50:31016.

4 Grompe M, Caskey T, Fenwick RG. Improved molecular diagnostics for ornithine transcarbamylase deficiency. $A m \mathcal{F}$ Hum Genet 1991;48:212-22.

5 Segues B, Veber PS, Rabier D, et al. A 3-base pair in-frame deletion in exon 8 (delGlu272/273) of the ornithine transcarbamylase gene in late-onset hyperammonemic coma. Hum Mutat 1996;8:373-4

6 Oppliger-Leibundgut E, Wermuth B, Colombo J-P, LiechtiGallati S. Ornithine transcarbamylase deficiency: characterization of gene mutations and polymorphism. Hum Mutat 1996;8:333-9. 